\title{
Tannréttingameðferð með skinnum
}

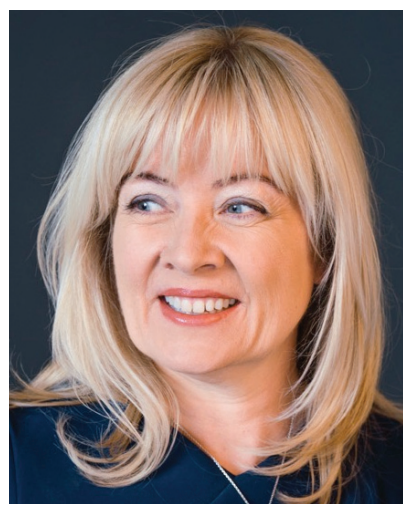

\author{
KRISTÍN HEIMISDÓTTIR, CAND. ODONT, SÉRFR/EĐINGUR I TANNRÉTTINGUM \\ LEKTOR I TANNRÉTTINGUM, TANNLÆKNADEILD HÁSKÓLA ÍSLANDS
}

NETFANG: kristinhe@hi.is TANNLÆKNABLAĐIĐ 2020; 38: 47-50

doi: 10.33112/tann.38.1.5

\section{ÁGRIP}

Síðastliðin ár hefur notkun skinna til að rétta tennur stóraukist í tannlækningum. Nýleg könnun leiddi í ljós að meirihluti íslenskra tannlækna hafa kynnt sér pennan meðferðarmöguleika og stefna jafnvel að pví að bjóða upp á hann sem hluta af heildarmeðferð. Allir íslenskir tannréttingasérfræðingar sem og nokkrir almennir tannlæknar bjóða nú pegar upp á skinnumeðferð. Skinnur eru ýmist notaðar til að rétta stakar tennur til að laga minniháttar tannskekkjur eða pá sem hluti af heildarmeðferð í flóknari tilfellum. Í völdum tilfellum og pegar mikill samstarfsvilji sjúklings er fyrir hendi geta skinnur skilað góðum árangri. Mikilvægt er að greina tilfellin vel í byrjun og ætla sér ekki um of. Í greininni verður farið yfir tilurð tannréttingaskinna, ábendingar og frábendingar sem og kosti og galla.

Lykilorð: skinnur, tannréttingar, prengsli

\section{Inngangur}

Align company, brautryðjandi í skinnumeðferð, var stofnað árið 1997. Einungis tveimur árum síðar hófst framleiðsla skinna hjá fyrirtækinu og hefur próast æ síðan. Hugmyndin var ekki ný af nálinni, pví skinnur hafa verið notaðar til stuðnings eftir tannréttingameðferð frá áttunda áratug síðustu aldar og eru enn notaðar í stoðmeðferð (1). Fyrstu heimildir um notkun skinna til tannfærslu eru frá árinu 1946 (2), en pá hlaut hún ekki brautargengi. Hugmyndin byggir á pví að mynda prýsting í skinnu til að færa tennur til. Forsenda pess að hægt sé að hreyfa tennur með pessum hætti er að skinnan sé nægilega lengi í munni til að tyggikraftar og önnur starfsemi tyggingarfæra færi tennur ekki aftur til baka. Almennt viðmið er 22ja klukkustunda notkun á sólarhring (3). Ýmis efni hafa verið notuð í skinnurnar, en pau eiga öll sameiginlegt að vera hitapjál. Pykkt og styrkleiki er mismunandi, en algengasta pykkt er 0.4mm (4). Pegar margar skinnur eru notaðar í röð, er færsla tannar takmörkuð við 0.2mm í hverri skinnu. Ástæða pess er takmörkuð pangeta skinnu en einnig virðist svo væg færsla valda minni ópægindum (5).

\section{Meðferðaráætlun}

Mikilvægt er að greining í byrjun sé ítarleg. Almennt heilsufar, ástand í munni og heilbrigði er metið, ástand tannhalds og ekki síst, samvinna sjúklings. Miðlínur andlits, vara, og skekkjur í andliti parf að greina og mikilvægustu spurningunni verður að svara, en hún lýtur að tilgangi meðferðar. Sama gildir og hjá öllum tannréttingasjúklingum, hvort hægt sé að uppfylla óskir sjúklings ásamt pví að leysa pau vandamál sem tannlæknir greinir. Meðferðaráætlun er 
gerð með fullum tannréttingagögnum p.m.t. ljósmyndum innan og utan munns. Halli tanna og kjálkabygging er greind á hliðarröntgenmynd með tilheyrandi mælingum ásamt breiðmynd og hugsanlega styrkt stökum smámyndum. Skann eða afsteypur af tönnum sjúklings eru nauðsynlegar. Áður var eingöngu notast við gifsafsteypur en nú eru munnskannar orðnir alls ráðandi í stafrænum heimi. Könnun á meðal íslenskra tannlækna leiddi í ljós að rúmlega fimmtungur peirra $(21,9 \%)$ notar munnskanna í stað hefðbundinna alginatmáta og gifsafssteypa (6).

pegar gögn ásamt meðferðaráætlun liggja fyrir, er hægt að senda gögnin í gegnum forrit til fyrirtækja sem framleiða skinnurnar. Pau eru allnokkur og má nefna Invisalign, OrthoClear og Clear Correct sem dæmi. Hugbúnaður er nokkuð próaður og í stöðugri framför, en ekki má gleyma pví að sá sem móttekur gögnin, hefur aldrei séð sjúklinginn og treystir eingöngu á pær upplýsingar sem berast frá tannlækni

Hugbúnaður hefur einnig verið próaður til notkunar á prívíddarprentara sem gerir tannlæknum kleift að prenta afsteypur á eigin stofu, sem skinnur eru gerðar á. Reikna má með talsverðri próun pessarar tækni í náinni framtíð. Tannlæknar sem nota pessa tækni nú, gera pað eingöngu í einföldum tilfellum.

Pegar búið er að vinna úr gögnum tannlæknis ytra, kemur tillaga til skoðunar sem oft er nefnd ClinCheck á ensku. Mikilvægt er að skoða hana vel og betrumbæta ef parf. pegar tannlæknir sampykkir ClinCheck, hefst framleiðsla skinnanna. pá eru pær sendar tannlækni sem getur hafið meðferð,

\section{Meðferð}

Í ferlinu getur tannlæknirinn purft að grípa inn í með hnúðum og kubbum (e. engagers), sem festir eru á tennur til að auka prýsting og par með færslu tanna (Mynd 1).

Mynd 1. Skýringarmynd frá ClearCorrect, par sem sýnt er hvar bæta á við prýstihnúðum.

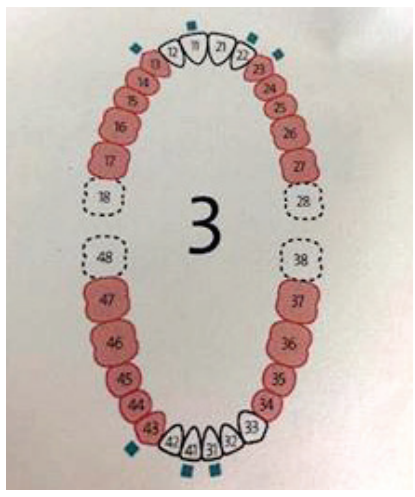

Einnig getur purft að stripsa (e. IPR - interproximal enamel reduction). Slíkt er ákveðið fyrirfram og mikilvægt að grípa inn í á réttum stað í meðferðinni. Hóflegur niðurskurður á glerungi er í flestum tilfellum skaðlaus, en muna parf að hann er óafturkræfur. Alls ekki er ráðlagt að taka meira en $0.5 \mathrm{~mm}$ af t.d. framtönnum í neðri gómi. Gott er að bera flúor á fletina eftir að stripsað hefur verið pví viðkvæmni við kuli/ hita getur orðið. Alltaf ætti að gera Bolton-greiningu áður en ákveðið er að stripsa.

Mikilvægt er að fylgjast með ferlinu öllu, hvort skinnurnar setjist rétt og pétt. Algengast er að skipta um skinnur á tveggja vikna fresti, en pað er engin alhlít regla. Ef tennur eru ekki vel skorðaðar í skinnu eftir notkun getur pað pýtt að færsla hafi verið of mikil eða skortur hafi verið á samvinnu sjúklings. Gagnslaust að halda pá áfram pví næsta skinna

Hvað er Bolton-misræmi? (1)

Til að bit gangi upp, purfa tennur að vera í hlutfallslega réttri stærð. Ef tennur eru stórar i efri og litlar í neðri góm, eins og ef tannaspjöld með tönnum af mismunandi stærð eru notuð til að stilla upp heilgómasetti, næst aldrei ákjósanlegt bit (ideal occlusion). Oftast er samræmi í náttúrulegu tannsetti, en pó er ákveðið misræmi tannbreidda hjá um $5 \%$ einstaklinga. Petta misræmi birtist oft hjá einstaka tönnum eins og hliðarframtönnum efri góms (tapptennur), en getur pó birst hjá öllum tönnum.

Hvernig metum við misræmi tannbreidda?

Breidd tanna er mæld, annaðhvort frá augntönn til augntannar eða frá sexu til sexu. Breiddir tanna eru lagðar saman og summur peirra (efri og neðri góms) bornar saman í sérstakri töflu. Til að nefna dæmi, getur samanlögð breidd tanna $13-23$ verið $46 \mathrm{~mm}$ og samanlögð breidd $33-4338,6 \mathrm{~mm}$. Pegar farið er í töfluna, kemur í ljós að misræmið er 3,1mm í neðri (ofgnótt) eða $4 \mathrm{~mm}$ í efri (skortur).

Skannar og forrit í dag geta gert pessa greiningu sjálfvirkt, en mikilvægt er að skilja hvað petta pýðir.

Af hverju skiptir petta máli í skinnumeðferð? pað er töluvert algengt að ætlast sé til pess að tekið sé af hliðarflötum tanna (stripsað - IPR) í skinnumeðferð. Pví er mikilvægt að átta sig á pví hvort misræmi tannabreidda sé til staðar, svo ekki sé stripsað út í bláinn. Í ofangreindu dæmi væri beinlínis rangt að stripsa í efri gómi, en pað gæti komið sér ágætlega að mjókka tennur í neðri, ef form tanna leyfir. 
passar enn verr.

\section{Kostir og gallar}

Tannrétting með skinnum hefur tvímælalaust talsverða kosti í för með sér. Eins og með öll laus tæki, er hægt að taka skinnurnar úr munni og prífa tennur vel og vandlega með eðlilegum hætti. Skinnurnar eru lítt sýnilegar (Mynd 2), og valda sjaldan sárum í kinn eða tungu.

Mynd 2. Einstaklingur með skinnur í efri og neðri (úr einkasafni).

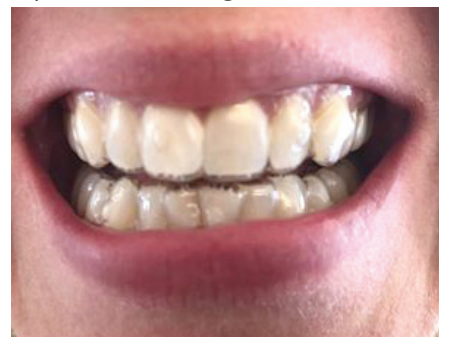

Tannfærsla er hæg og pví talið að ópægindi séu minni. Nýlegar rannsóknir benda pó til pess að lítill munur sé á ópægindum í skinnumeðferð og meðferð með föstum tækjum (7). Hægt er að fylla upp í tannlaus bil með tannlituðu plasti á meðan á meðferð stendur.

En pað er engin rós án pyrna. Réttar ábendingar og samvinna sjúklings er lykilatriði í meðferð með skinnum. Að nota skinnur 22 klukkustundir á dag krefst mikillar samvinnu, sem er ekki alltaf fyrir hendi. Sumar skinnur geta valdið erfiðleikum við tal, en slíkt venst pó jafnan við stöðuga notkun. Dæmi eru um einstaklinga sem vegna vinnu (kennarar, símsvörun) hafa ekki treyst sér til að venjast skinnum. Meðferðartíminn getur stundum verið styttri en með föstum tækjum, en getur einnig verið töluvert lengri, sérstaklega í flóknari tilfellum. Í völdum tilfellum getur verið skynsamlegt að hefja meðferð með föstum tækjum og klára með skinnum (1).

Helstu frábendingar tannréttinga með skinnum lúta að aldri sjúklinga, erfiðum snúningum tanna og innilokuðum tönnum (1). Erfiðara er að ná samvinnu barna og unglinga, sérstaklega með notkun á lausum tannréttingatækjum. Prátt fyrir einlægan ásetning og vilja, eru lausu tækin mun minna í munni en mælst er til (8). Erfitt getur verið að snúa mjög snúnum tönnum og oft bæði einfaldara og fljótlegra að nota föst tæki. pað segir sig sjálft að innilokaðar tennur verða ekki sóttar með skinnum.

\section{Umræða}

Tannréttingar með skinnum er nýr og spennandi meðferðarkostur par sem stafræn tækni er nýtt. Íslenskir tannlæknar hafa verið duglegir að kynna sér pessar nýjungar. Í nýlegri könnun (6) kom fram að 54,4\% tannlækna hafa kynnt sér meðferðarmöguleikann og tæp 15\% bjóða skinnumeðferð fyrir sjúklinga sína. Má ætla að pessi meðferð muni njóta frekari vinsælda í framtíðinni meðal eldri sjúklinga sem vilja einungis halda öllum tönnum heldur einnig hafa pær beinar og fínar. Stafræn tækni virkar vel á tölvuskjá, en rannsóknir hafa pví miður leitt í ljós að skinnumeðferð skilar oft ekki nema helmingi færslu sem til stóð (mean 50\%) (9). Best reyndist færsla á búkkó-lingual krónuhluta tannar (56\%) en lakar reyndust snúningsfærslur augntanna, forjaxla og jaxla (46\%). pað eru betri niðurstöður en fyrri rannsókn frá árinu 2009, par sem meðalfærsla reyndist aðeins $41 \%$ af peirri færslu sem áætluð var (10). pað er vísbending um að kerfin séu á réttri leið. Kostnaður við tannréttingu með skinnum er sambærilegur við hefðbundnar tannréttingar. Talsverður framleiðslukostnaður leggst til í byrjun og pví verið afar óheppilegt ef allar skinnur eru tilbúnar og sjúklingur telur sig ekki geta notað pær, en nokkur dæmi eru um slíkt.

Ákveðnir framleiðendur tannréttingaskinna stunda grimma markaðssetningu og vísa óhikað í eigin rannsóknir par sem kemur fram að skinnumeðferð sé fljótvirkari, nútímalegri, sársaukaminni, ódýrari og betri en hefðbundin tannréttingameðferð (Mynd 3).

\section{Invisalign}

Sponsored $\cdot 6$

You've upgraded from cassette players and VHS tapes, so why trust your smile to outdated technology? Update your smile with the most advanced clear aligner system in the world.

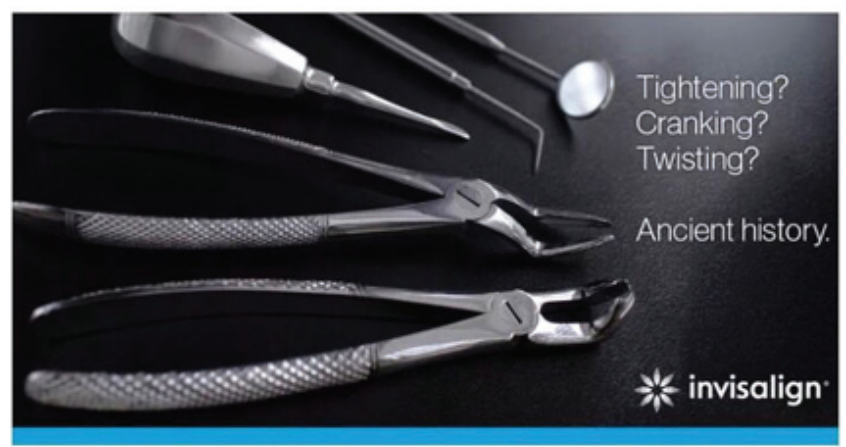

The Modern Way to a Better Smile

Learn More

Mynd 3. Úr auglýsingaherferð Invisalign árið 2017 
Athyglisvert er að sjá umræður og ályktanir á spjallrás heimasíou Invisalign Kanadísk samantektarrannsókn (systematic review) sýndi að hefðbundin tannrétting með föstum tækjum stendur tannréttingu með skinnum framar, enn sem komið er (11). Gott er að hafa í huga að fyrirtæki sem framleiða vöru og búa yfir markaðsdeild, nota ýmsar aðferðir til að sannfæra fólk um ágæti vöru sinnar; aðferðir sem heilbrigðisstarfsfólki er ekki tamt að nota. pað pýðir ekki að varan sé slæm, en ekki heldur að hún henti öllum.

Notkun skinna í tannréttingum getur verið afar ákjósanlegur kostur í hentugum tilvikum. Hentug tilvik eru væg eða meðalprengsli eða gleiðstaða upp á 1-6mm á framtannasvæði, par sem kjálkar passa saman í sagittal sniði.
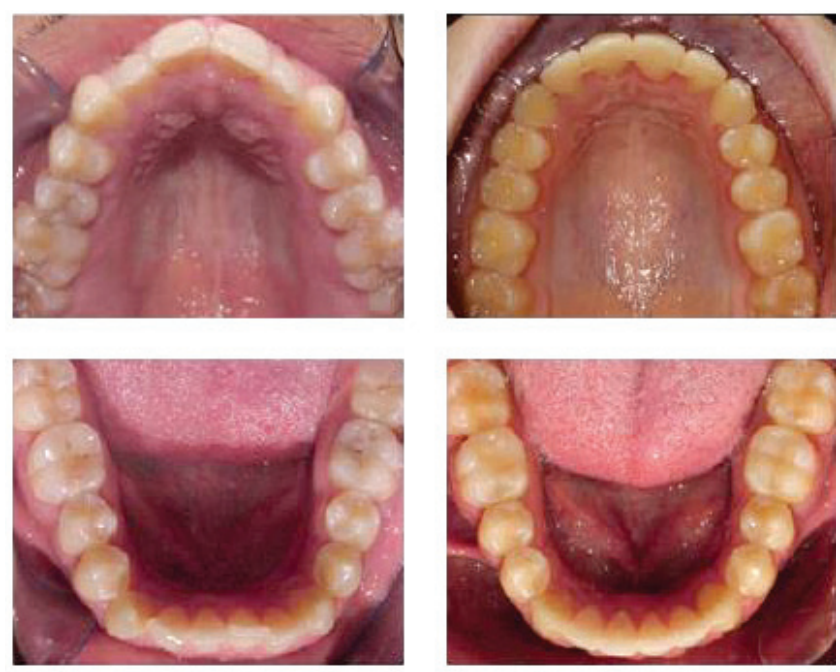

Mynd 4. Væg prengsli, hlutlaust bit. Nokkurra mánaða skinnumeðferð skilaði góðum árangri.
Afar vel hefur reynst að nota skinnumeðferð til stuðnings eða laga bakslag eftir tannréttingameðferð. Margt bendir til pess að skinnumeðferð henti ekki börnum og unglingum í tannskiptum (2).

Skinnumeðferð getur pó snúist upp í andhverfu sína sé meðferðaráætlun illa gerð og undirbúningi ábótavant.

\section{Heimildir}

1. Proffit WR., Fields HW., Larson BE.,Sarver DE. Contemporary Orthodontics, sixth edition 2019, Philadelphia, Elsevier.

2. Rossini, G., Parrini, S., Castroflorio, T., Deregibus, A., Debernardi Cl., Efficacy of clear aligners in controlling orthodontic tooth movement: a systematic review. Angle Orthod; 2015; 85(5), 881-889.

3. Zheng M., Liu R., Ni Z., Yu Z. Efficiency, effectiveness and treatment stability of clear aligners: A systematic review and meta-analysis. Orthod Craniofac Res; 2017; 20(3), 127-133.

4. Dasy H., Dasy A., Asatrian G., Rozsa N, Lee HF., Kwak.. Effects of variable attachment shapes and aligner material on aligner retention; Angle Orthod; 2015; 85(6), 934-940.

5. Boyd RL., Waskalic V. Three-dimensional diagnosis and orthodontic treatment of complex malocclusions with the Invisalign appliance. Seminars in Orthodontics; 2001; 7(4), 274-293.

6. Sigurjónsdóttir JÓ. Tannréttingaskinnur - almenn pekking og algengi notkunar; BS thesis, University of Iceland 2019.

7. Meiya G. et al. Comparison of pain perception, anciety and impacts on oral healthrelated quality of life between patients receiving clear aligners and fixed appliances during the initial stage of orthodontic treatment. European Journal of Orthodontics; 2020;1-7doi:10.1093.

8. Dalva AM., Salazar FC., Pandis N., Fleming PS. Compliance with removable orthodontic appliances and adjuncts: A systematic review and meta-analysis; Am J Orthod Dentofac Orthop; 2017; 152(1):17-32.

9. Haouili N., Kravitz ND., Vaid NR., Ferguson DJ., Makki L. Has Invisalign improved? A prospective follow-up study on the efficacy on tooth movement with Invisalign: Am J Orthod Dentofac Orthop 2020;Jun30:S0889-5406(20)30303 Ath

10. Kravitz ND.,Kusnoto B.,BeGole E.,Obrez A.,Agran B. How well does Invisalign work? A prospective clinical study evaluating the efficacy of tooth movement with Invisalign: Am J Orthod Dentofacial Orthop 2009;135:27-35.

11. Robertson L., Harsimrat K., Fagundes NCF., Major P., Mir CF. Effectiveness of clear aligner therapy for orthodontic treatment: A systematic review. Orthod Craniofac Res 2020 May;2382):133-142.

English Summary

\section{Orthodontic treatment with clear aligners}

KRISTIN HEIMISDOTTIR, DDS, ASSISTANT PROFESSOR, HEAD OF ORTHODONTICS, FACULTY OF ODONTOLOGY, UNIVERSITY OF ICELAND. ICELANDIC DENTAL JOURNAL 2020; 38: 47-50

doi: $10.33112 / \operatorname{tann} .38 .1 .5$

In recent years, the use of clear aligners for orthodontic treatment has become very popular. A recent survey revealed that the majority of Icelandic dentists find this treatment modality attractive and plan to offer clear aligners as a part of a total treatment. All Icelandic orthodontists offer orthodontic treatment with aligners as well as a few general dentists. Clear aligners can be a good treatment choice for mild orthodontic cases, but also for more complicated cases, even combined with fixed appliances. An essential issue is the patient's compliance and a proper treatment planning before starting the treatment. This article addresses the indications and contra-indications for the use of aligners in orthodontic treatment.

Keywords: Aligners, orthodontics, crowding

Correspondence: Kristín Heimisdóttir, e-mail: kristinhe@hi.is 